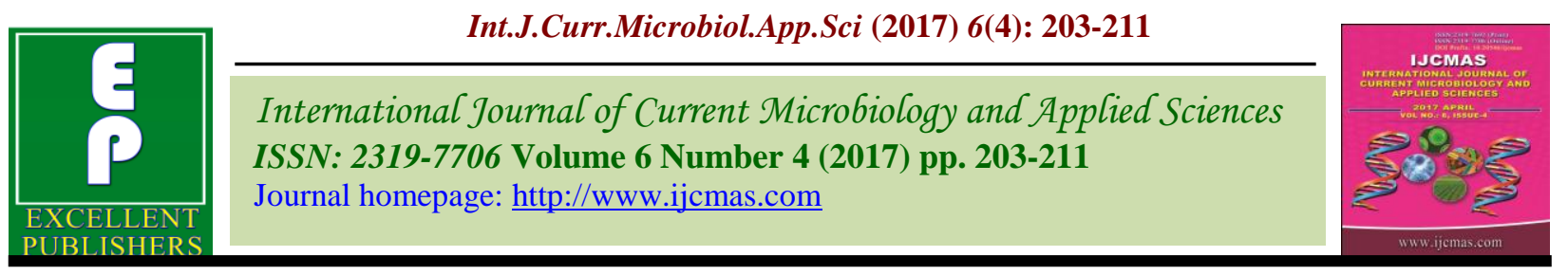

Original Research Article

https://doi.org/10.20546/ijcmas.2017.604.024

\title{
Impact of Mountain Cropping Systems on Soil Properties, Nutrient Availability and Their Carbon Sequestration Potential in Mid-Hills of Himachal Pradesh, India
}

\author{
C.K. Ndungu*, S.K. Bhardwaj and L. Nancy \\ Department of Environmental Science, Dr. Y S Parmar University of Horticulture \\ and Forestry, Nauni (Solan) India \\ *Corresponding author
}

\section{A B S T R A C T}

\begin{tabular}{|l|}
\hline K e y w o r d s \\
Cereal crops, \\
Vegetable crops, \\
Fruit crops, \\
Agroforestry, \\
NPK, Adaptation, \\
Mitigation. \\
\hline Article Info \\
\hline $\begin{array}{l}\text { Accepted: } \\
\text { 02 March } 2017 \\
\text { Available Online: } \\
\text { 10 April } 2017\end{array}$ \\
\hline
\end{tabular}

\section{Introduction}

The productivity of our planet's ecosystems depends upon the nature of the soil and its quality. The crop production and environmental quality can be sustained by maintaining this important natural resource on sustainable basis. However, to meet the increasing demand of burgeoning population, agriculture is being commercialised everywhere and it has become a high input system. The high input systems have now started impacting soil quality and ultimately the nature of ecosystem services (Feng et al., 2010). Moreover, the commercialization of agriculture has led to adoption of high yielding crop varieties whereby one type of crop is continuously cultivated on one plot in an attempt to increase yields. This monoculture farming system interferes with 
the soil's ability to provide essential ecosystem services such as soil health and carbon sequestration. The monoculture farming reduces soil carbon, promotes adverse soil reactions and ultimately reduces nutrient availability.

In recent years a concern is being expressed at global level that chemical based energy intensive modern agriculture is threatening the natural resource systems through contamination of soil and water bodies, global warming and ecological degradation. In India, the green revolution technologies during the last few decades have helped to achieve selfregulating sufficiency in food grain production, but emergent of many new and unexpected problems have created a spectre of unsustainability in cropping systems. These problems are related to emergence of nutrient deficiencies, soil and environmental degradation. To address these issues and the long term impact of different cropping systems, the assessment of their long term impact on soil and environmental quality is now being stressed.

Agriculture soils are among the planet's largest reservoirs of carbon and hold potential for expanded carbon sequestration and thus provide a prospective way of mitigating the increasing atmospheric concentration of carbon dioxide. It is estimated that soils can sequester around $20 \mathrm{Pg} \mathrm{C}$ in 25 years, more than $10 \%$ of the anthropogenic emissions (Liu et al., 2005). At the same time, soil organic carbon provides other benefits for soil, crop, environmental quality, enhancement of biodiversity and prevention of erosion and desertification.

In the recent past, dramatic changes in the agricultural land use and associated management practices have happened in midhills of Himachal Pradesh. Increasing commercialisation of agriculture and spread of market oriented horticulture has led to adoption of high input demanding cropping systems on steep and sloppy areas, thereby exposing the region to various environmental problems. Therefore, the current study was conceived with the objective of exploring the impacts of cropping systems on soil quality and its carbon sequestration potential in the region.

\section{Materials and Methods}

\section{Study area}

The study area consisted of mid-hill (800$1600 \mathrm{~m}$ above mean sea level) regions falling in two districts namely Kullu and Solan of Himachal Pradesh in North Western Himalayas. The region has mild temperate climate with annual average rainfall of about $1150 \mathrm{~mm}$. The soils vary from sandy loam to loam in texture. The area has a steep and rugged terrain which amplifies biophysical and socioeconomic vulnerability of the communities. The mid-hills cover an area of about $33 \%$ of the total geographical area and $53 \%$ of the cultivated area of the state. The study area selected in mid-hills of Kullu and Solan districts of HP is depicted in figure 1.

\section{Cropping systems and experimental details}

The four cropping systems i.e. fruit, vegetable, cereal and agroforestry based were selected in mid-hills of Kullu and Solan districts of Himachal Pradesh. The selected systems were replicated six times and barren land was considered as control. The study was conducted under randomized block design, with five treatments.

The fruit farming system was composed of apple, apricot, pomegranate or peach crops. The vegetable farming system was composed of cabbage, capsicum or potato crops. Cereal based farming system was maize and wheat based while agroforestry system was composed of agri-silviculture or agri- 
horticulture. The total area under vegetable, fruit, cereal and agroforestry system was about 44249.7ha, 113724ha, 410866ha and $121900 \mathrm{ha}$, respectively whereas it was 258523.2ha as barren land in mid-hills of Himachal Pradesh (Anonymous, 2012). Amongst the four dominant cropping systems in mid-hills of Himachal Pradesh, the cereal based and agroforestry were the oldest systems and are being followed by the mountain people for the last about 50 years. On the other hand fruit and vegetable based cropping system are being practiced for the last 30 and 15 years, respectively. Vegetable cropping system was noticed to be the recent one, having been followed by the farmers for the last 15 years. Among the selected cropping systems, fruit and vegetable systems were noticed to be high input based wherein farm yard manure and NPK fertilizers are applied at a rate of $900-1000 \mathrm{~kg} \mathrm{ha}^{-1}$ and 700:350:700g per tree- 200:112.5:75 $\mathrm{kg} \mathrm{ha}^{-1}$, respectively.

\section{Soil sampling and analysis}

Composite soil samples from surface and subsurface layers were taken from each cropping system during year 2014 and 2015 and transported to the laboratory for processing and analysis. Soil samples were air dried, ground and sieved $(2 \mathrm{~mm})$ before laboratory examination. The soil bulk density was estimated by core method (Singh, 1980). Soil organic carbon was determined by rapid titration method (Walkley and Black, 1934). The available nitrogen was estimated by alkaline potassium permanganate method (Subbiah and Asijia, 1956) and available phosphorus by using Olsen's method (Olsen et al., 1954). The available potassium was estimated by ammonium acetate method (Merwin and Peech, 1951). Soil electrical conductivity and $\mathrm{pH}$ was determined by $1: 2.5$ soil: water suspension method (Jackson, 1973). The soil organic carbon stock Qi (Mg $\mathrm{ha}^{-1}$ ) was computed by multiplying the soil carbon content (\%) with bulky density Di (g $\mathrm{m}^{3}$ ), volume fraction of coarse fragments $\mathrm{Gi}$ and depth Ei (m) and expressed as $\mathrm{Mg} \mathrm{C} \mathrm{ha}{ }^{-1}$ as per the following formula given by Batjes (1996).

\section{QI=CiDiEi (1-Gi)}

The total amount of carbon sequestered by each cropping system in mid-hills of Kullu and Solan districts of Himachal Pradesh was computed by multiplying the mean carbon stock per hectare by the total area.

\section{Statistical analysis}

Analysis of variance (ANOVA) was used to evaluate the influence of cropping systems on soil physical chemical properties, nutrient contents and carbon stocks in mid-hills of Himachal Pradesh. The means were separated and compared through critical difference at $5 \%$ level of significance. In order to depict the long term impact of cropping systems on the soil properties and soil carbon stock the data with respect to the various parameters was pooled for both the years.

\section{Results and discussion}

\section{Soil properties}

In mid-hills of Himachal Pradesh, the commonly followed cropping systems have been found to exert significant influence on soil properties (Table 1). Soil organic carbon ranged from $0.83 \%$ to $1.75 \%$ in surface soil. The cropping system wise trend of soil organic carbon in surface soil was; fruit based $(1.75 \%)>$ agroforestry $(1.63 \%)>$ vegetable based $(1.41 \%)>$ cereal based $(1.00 \%)>$ control $(0.83 \%)$. The sub-surface soil organic carbon was lower compared to surface soil organic carbon but it followed the same trend as that of surface soil. 
The highest soil organic carbon observed in fruit based compared to the other cropping systems and control was probably due to regular application of farm yard manure under such highly remunerative systems in mid-hills of Himachal Pradesh. The results are in conformity with findings of Jing et al., (2012) and Cheng et al., (2011). The relatively high soil organic carbon under agroforestry system as compared to cereal, vegetable and control can be attributed to high litter fall contribution under such systems. The results are in agreement with the findings of Balkrishan and Toky (1993) who attributed high amount of organic carbon in agroforestry systems to trees and specifically their habit of shedding leaves and presence of deep roots in the soil. Vegetable based cropping system had a relatively higher soil organic carbon compared to cereal crop which may be attributed to regular application of organic manure under this commercial system of farming in the region. Compared to fruit based cropping system, the vegetable system registered relatively low soil organic carbon in spite of higher farm yard manure application. This trend may be attributed to intensive cultivation under such systems which might have resulted in decomposition of soil organic matter.

Soil bulk density in surface soil ranged from $1.25 \mathrm{Mg} \mathrm{m}^{-3}$ to $1.27 \mathrm{Mg} \mathrm{m}^{-3}$. Under the different cropping systems, the soil bulk density followed the descending order; control $\left(1.27 \mathrm{Mg} \mathrm{m}^{-3}\right)>$ vegetable $(1.25) \mathrm{Mg}$ $\mathrm{m}^{-3}$ cereal $\left(1.24 \mathrm{Mg} \mathrm{m}^{-3}\right)>$ fruit $\left(1.23 \mathrm{Mg} \mathrm{m}^{-3}\right)$ $>$ agroforestry $\left(1.21 \mathrm{Mg} \mathrm{m}^{-3}\right)$. The sub-surface bulk density was higher compared to surface soil bulk density but the trend under the different cropping systems was the same. The lowest soil bulk density observed in agroforestry compared to other cropping systems and control can probably be attributed to more litter fall and relatively less disturbance due to minimum tillage of the soil. The results are in agreement with findings of Balkrishan and Toky (1993) who also reported low bulk density in agroforestry systems. The relatively low soil bulk density observed in fruit and vegetable based cropping systems compared to cereal crop and control can be ascribed to application of high doses organic manure under such systems in mid-hills of Himachal Pradesh. The results are in consonance with the findings of Zhang et al., (2006) who reported a significant reduction of soil bulk density compared to non-treated control in wheat-maize rotation after 13 years of organic manure application. The results are also in agreement with the findings of Anderson et al., (1990).

The $\mathrm{pH}$ in soil surface layer ranged from 6.28 to 6.95. It followed the descending order; control (6.95) > agroforestry (6.62) > cereal (6.49) > vegetable (6.30) > fruit (6.28) under the different cropping systems. Under the different cropping systems, the soil $\mathrm{pH}$ in subsurface soil was lower compared to surface soil $\mathrm{pH}$ but followed the same trend. The slightly acidic soil $\mathrm{pH}$ observed in fruit and vegetable based systems compared to the other cropping systems and control can be ascribed to addition of acid forming chemical fertilizers. The results are in consonance with findings of other workers who have also reported slightly acidic soil $\mathrm{pH}$ in cropping systems characterised by application of ammonium based fertilizers (Abad et al., 2014; Jing et al., 2012). The results further indicated that the cropping systems being followed since long time in the region have not influenced soil $\mathrm{pH}$ adversely and is still in the normal range.

The electrical conductivity in surface soil ranged from 0.58 to $0.66 \mathrm{dSm}^{-1}$. Under the different cropping systems, it followed the descending order; vegetable $\left(0.66 \mathrm{dSm}^{-1}\right)>$ fruit $\left(0.44 \mathrm{dSm}^{-1}\right)>$ agroforestry $\left(0.40 \mathrm{dSm}^{-1}\right)$ $>$ cereal crop $\left(0.36 \mathrm{dSm}^{-1}\right)>$ control $(0.35$ $\left.\mathrm{dSm}^{-1}\right)$. Sub-surface soil electrical conductivity was observed to be lower 
compared to surface soil but trend crop system wise was the same. However, it was normal under all the systems indicating that the common cropping systems of the region have not influenced salt concentration of the soils. The results are in line with findings of Hati et al., (2007) who reported soil electrical conductivity in the normal range in soya bean-maize-wheat rotation after 28 years of organic and inorganic fertilizer application.

Table.1 Distribution of organic carbon, bulk density, $\mathrm{pH}$ and electrical conductivity in surface and sub-surface soil under different cropping systems in mid-hills of Himachal Pradesh

\begin{tabular}{ccccccccc}
\hline \multirow{2}{*}{$\begin{array}{c}\text { Cropping } \\
\text { systems }\end{array}$} & \multicolumn{9}{c}{ Soil physico-chemical properties } \\
\cline { 2 - 8 } & Organic carbon (\%) & \multicolumn{2}{c}{ Bulk density $\left(\mathbf{M g ~ m}^{-3}\right)$} & \multicolumn{2}{c}{$\mathbf{p H}$} & \multicolumn{2}{c}{ EC $\left(\mathbf{d S m}^{-1}\right)$} \\
\cline { 2 - 8 } & Surface & $\begin{array}{c}\text { Sub- } \\
\text { surface }\end{array}$ & Surface & $\begin{array}{c}\text { Sub- } \\
\text { surface }\end{array}$ & Surface & $\begin{array}{c}\text { Sub- } \\
\text { surface }\end{array}$ & Surface & $\begin{array}{c}\text { Sub- } \\
\text { surface }\end{array}$ \\
\hline Vegetable & 1.41 & 1.25 & 1.25 & 1.28 & 6.30 & 5.86 & 0.66 & 0.48 \\
Fruit & 1.75 & 1.23 & 1.23 & 1.24 & 6.28 & 5.83 & 0.64 & 0.44 \\
Cereal & 1.00 & 1.24 & 1.24 & 1.26 & 6.49 & 6.05 & 0.58 & 0.36 \\
Agroforestry & 1.63 & 1.21 & 1.21 & 1.25 & 6.62 & 6.17 & 0.60 & 0.40 \\
Barren land & 0.83 & 1.27 & 1.27 & 1.30 & 6.95 & 6.51 & 0.58 & 0.35 \\
CD $_{\mathbf{0 . 0 5}}$ & 0.09 & 0.12 & 1.76 & 1.80 & 0.07 & 0.07 & 0.04 & 0.06 \\
\hline
\end{tabular}

Table.2 Status of carbon density and total stocks under different cropping systems in mid-hills of Himachal Pradesh

\begin{tabular}{|c|c|c|c|c|c|c|}
\hline \multirow[t]{2}{*}{$\begin{array}{l}\text { Cropping } \\
\text { system }\end{array}$} & \multicolumn{2}{|c|}{$\begin{array}{l}\text { Carbon density (Mg C } \\
\left.\text { ha }^{-1}\right)\end{array}$} & \multirow[t]{2}{*}{$\begin{array}{l}\text { Area in } \\
\text { hectare }\end{array}$} & \multicolumn{2}{|c|}{$\begin{array}{l}\text { Soil layer wise carbon stock } \\
(\mathrm{Mg} \mathrm{C})\end{array}$} & \multirow[t]{2}{*}{$\begin{array}{l}\text { Total carbon stock } \\
\text { (Gg C) }\end{array}$} \\
\hline & Surface & Subsurface & & Surface & Subsurface & \\
\hline Vegetable & 18.13 & 15.90 & 51102.1 & 926481.1 & 812523.4 & 1739.00 \\
\hline Fruit & 20.60 & 19.09 & 70809.42 & 1458674 & 1351752 & 2810.43 \\
\hline Cereal & 14.01 & 11.37 & 370199.5 & 5186495 & 4209168 & 9395.66 \\
\hline Agroforestry & 19.08 & 17.29 & 144001.4 & 2747547 & 2489785 & 5237.33 \\
\hline Barren land & 10.71 & 8.41 & 53426.88 & 572201.9 & 44932.1 & 1021.52 \\
\hline $\begin{array}{l}C_{0.05} \\
\text { Total }\end{array}$ & 1.76 & 1.80 & - & - & - & $\begin{array}{c}- \\
20203.95\end{array}$ \\
\hline
\end{tabular}

Table.3 Distribution of available NPK content under different cropping systems in mid-hills of Kullu and Solan districts of Himachal Pradesh

\begin{tabular}{|c|c|c|c|c|c|c|}
\hline \multirow[t]{3}{*}{ Cropping systems } & \multicolumn{6}{|c|}{ Available $\mathrm{N}, \mathrm{P}_{2} \mathrm{O}_{5}$ and $\mathrm{K}_{2} \mathrm{O}\left(\mathrm{kg} \mathrm{ha}^{-1}\right)$} \\
\hline & \multicolumn{2}{|r|}{$\mathbf{N}$} & \multicolumn{2}{|c|}{$\mathbf{P}_{2} \mathbf{O}_{5}$} & \multicolumn{2}{|c|}{$\mathrm{K}_{2} \mathrm{O}$} \\
\hline & Surface & Sub-surface & Surface & Sub-surface & Surface & Sub-surface \\
\hline Vegetable based & 555.45 & 526.14 & 42.62 & 34.17 & 447.23 & 378.19 \\
\hline Fruit based & 551.12 & 499.22 & 43.96 & 38.96 & 451.12 & 401.45 \\
\hline Cereal based & 412.00 & 366.25 & 25.27 & 18.28 & 307.92 & 258.00 \\
\hline Agroforestry & 533.27 & 492.91 & 30.68 & 25.68 & 428.94 & 379.27 \\
\hline Barren land & 303.76 & 258.74 & 20.62 & 16.36 & 198.87 & 151.14 \\
\hline$C D_{0.05}$ & 6.71 & 9.38 & 1.27 & 1.27 & 5.70 & 8.84 \\
\hline
\end{tabular}


Fig.1 Map of the study area showing the selected sites in mid-hills of HP

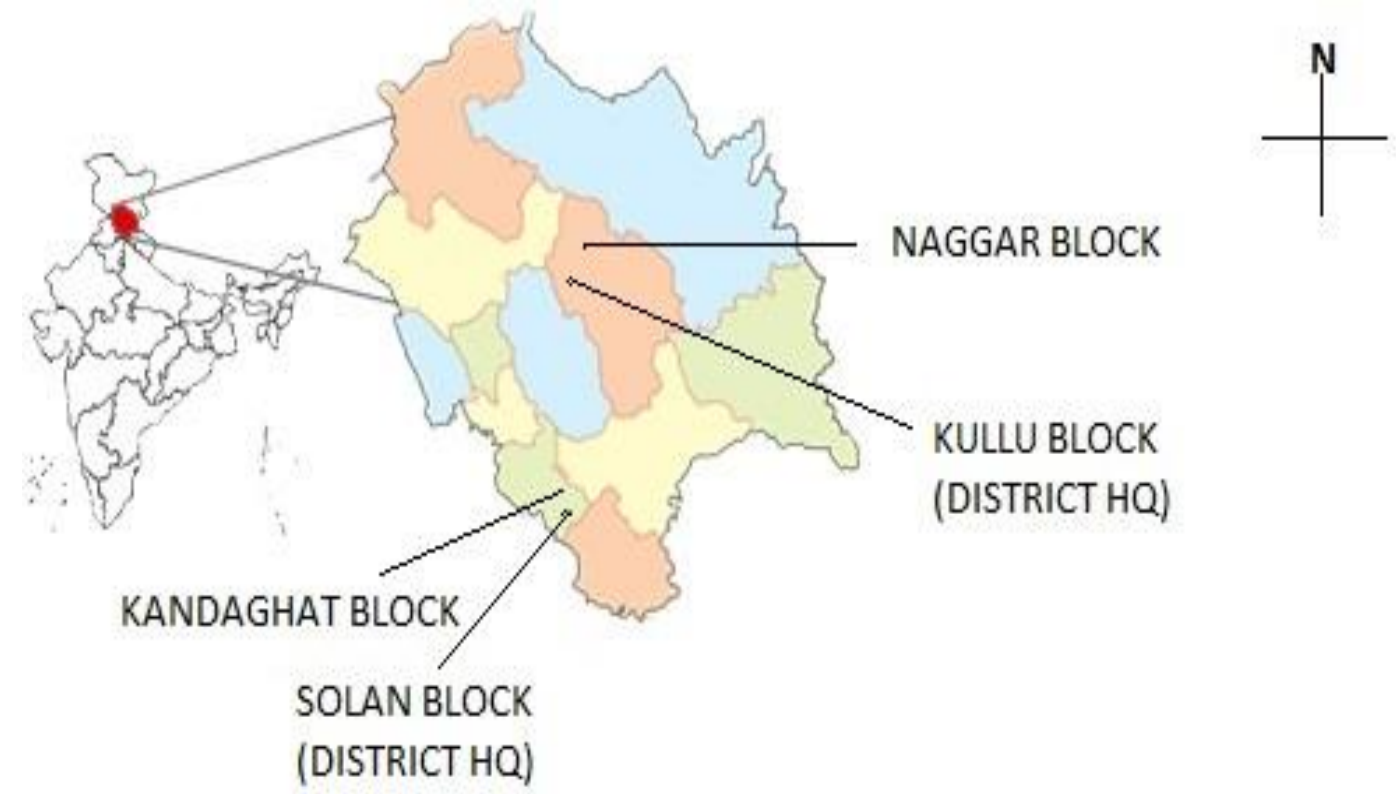

\section{Carbon density and total stock}

The cropping systems in mid-hills of Himachal Pradesh have been found to significantly influence the soil carbon sequestration potential in the region (Table 2). Carbon density of soil surface layer ranged from 10.71 to $20.60 \mathrm{Mg} \mathrm{C} \mathrm{ha}^{-1}$. It followed the descending order; fruit $\left(20.60 \mathrm{Mg} \mathrm{C} \mathrm{ha}^{-1}\right)$ $>$ agroforestry $\left(19.08 \mathrm{Mg} \mathrm{C} \mathrm{ha}^{-1}\right)>$ vegetable $\left(18.13 \mathrm{Mg} \mathrm{C} \mathrm{ha}^{-1}\right)>$ cereal $14.01\left(\mathrm{Mg} \mathrm{C} \mathrm{ha}^{-1}\right)$ $>$ control $\left(10.71 \mathrm{Mg} \mathrm{C} \mathrm{ha}^{-1}\right)$ under the different cropping systems. Total carbon sequestered ranged from 1021.52 to 9395.66Gg. The order for total carbon stock as influenced by the different cropping systems was cereal crop $(939.57 \mathrm{Gg})>$ agroforestry $(5237 \mathrm{Gg})>$ fruit $(2810.43 \mathrm{Gg})>$ vegetable $(1739.00 \mathrm{Gg})>$ control (1021.52Gg). In subsurface soil, the carbon stocks under the different cropping systems were lower compared to surface soil carbon stock but system wise the trend was the same.

The higher carbon density observed in fruit based compared to other cropping systems and control can be ascribed to addition of farm yard manure in each season, ostensibly to increase production and consequently the economic returns from this system. The results are in agreement with findings of Benbi and Brar (2009) who reported significant increase in carbon stocks in wheatmaize rotation in northern India after 36 years of organic manure application. Several other workers have reported higher amount of carbon stocks in cropping systems characterized by long time of organic manure application (Jing et al., 2012; Cheng et al., 2011; Babbu et al., 2015). The highest total carbon stock recorded in cereal crops is attributed to the big area devoted to their cultivation in mid-hills of Himachal Pradesh.

\section{Available nitrogen, phosphorus and potassium}

Perusal of data in table 3 shows that the cropping systems of mid-hills of Himachal Pradesh have significantly influenced the nutrient availability in the soil. Available nitrogen in soil surface ranged from 303.76 to 
$555.45 \mathrm{~kg} \mathrm{ha}{ }^{-1}$. The order of available nitrogen as affected by cropping systems in soil surface was vegetable $\left(555.45 \mathrm{~kg} \mathrm{ha}^{-1}\right)>$ fruit $\left(551.12 \mathrm{~kg} \mathrm{ha}^{-1}\right)>$ agroforestry $(533.27$ $\left.\mathrm{kg} \mathrm{ha}{ }^{-1}\right)>$ cereal $\left(412 \mathrm{~kg} \mathrm{ha}^{-1}\right)>$ control (303.76 $\left.\mathrm{kg} \mathrm{ha}^{-1}\right)$. Available phosphorus ranged from 20.62 to $43.96 \mathrm{~kg} \mathrm{ha}^{-1}$. It followed the order; fruit $(43.96 \mathrm{~kg} / \mathrm{ha})>$ vegetable $\left(42.62 \mathrm{~kg} \mathrm{ha}^{-1}\right)>$ agroforestry $\left(30.68 \mathrm{~kg} \mathrm{ha}^{-1}\right)>$ cereal $\left(25.27 \mathrm{~kg} \mathrm{ha}^{-1}\right)>$ control $\left(20.62 \mathrm{~kg} \mathrm{ha}^{-1}\right)$ under the different cropping systems. Available potassium ranged from 198.87 to $451.12 \mathrm{~kg} \mathrm{ha}^{-1}$. The order of available potassium as affected by cropping systems was fruit $451.12 \mathrm{~kg} \mathrm{ha}^{-1}>$ vegetable $\left(447.23 \mathrm{~kg} \mathrm{ha}^{-1}\right)>$ agroforestry $\left(428.94 \mathrm{~kg} \mathrm{ha}^{-1}\right)>$ cereal $\left(307.92 \mathrm{~kg} \mathrm{ha}^{-1}\right)>$ control (198.87 kg ha $\left.{ }^{-1}\right)$. In sub-surface soil, the available nutrient were lower compared to surface soil under the different cropping systems, but followed the same order.

The significantly higher amount of available nutrient recorded in fruit and vegetables compared to the other cropping systems and control can be ascribed to continuous application of inorganic fertilizers under such commercial systems of farming practices in mid-hills of Himachal Pradesh. The results are in consonance with findings of Cheng et al., (2011) who also reported higher amount of available nutrient in vegetable and fruit based cropping systems compared to cereal crop while working in China. Higher amount of available nutrients in agroforestry compared to cereal cropping system is probably due to better nutrient recycling under the farming system. The results are in the line with the finding of Balkrishan and Toky (1993) who reported soil surface enrichment with nutrients from the fall from trees of litter, twigs, branches and fruits in agroforestry system.

In conclusion the study indicated that in midhills of Himachal Pradesh, the soil nutrients contents, carbon stock and physical chemical parameters were significantly influenced by cropping systems and seasons. The level of influence of cropping system on the soil characteristics was determined by the intensity of cultivation of the cropping system in question. Cropping systems characterized by high inputs of farm yard manure and artificial fertilizers scored high in NPK nutrients and carbon. The study also indicated that in mid-hills of Himachal Pradesh fruit based cropping system is having highest potential of sequestering soil carbon and further it has improved the physico-chemical properties of the soil and also enhanced the nutrient availability. Therefore to adapt to changing climatic situation and to mitigate its effect in the region, fruit based cropping system need to be encouraged.

\section{Acknowledgement}

The first author is grateful to Indian Council of Cultural Relations (ICCR) for funding his PhD studies. The Department of Environmental Science, Dr. Y.S Parmar University of Horticulture and Forestry, Nauni- Solan (HP) India, is highly appreciated for providing facilities for conducting the study.

\section{References}

Abad, J.R., Khosravi, H. and Alamdarlou, E.H. 2014. Assessment of the effect of land use changes on soil physical chemical properties in Jafarabad of Golestan province, Iran. Bull. Env. Pharmacol. Life Sci., 3: 296-300.

Anderson, S.H., Gantzer, C.J., Brown, J.R. 1990. Soil physical properties after 100 years of continuous cultivation. J. Soil Water Conserv., 45: 117-121.

Anonymous. 2012. Annual season and crop report. Himachal Pradesh Government, Shimla. 
Babbu, S., Jagdeep, S., Gurbir, S and Gurpreet, K. 2015. Effects of long term application of inorganic and organic fertilizers on soil organic carbon and physical properties in maize-wheat rotation. Agron., 5: 220-238

Balkrishan, A. and Toky, O. 1993. Significance of nitrogen fixing in woody legumes in forestry. Indian Forester, 5: 126-132

Batjes, N.H. 1996. Total carbon and nitrogen in the soils of the world. European $J$. Soil Sci., 47: 151-163

Begum, F., Bajracharya, R.M., Sharma, S., Ali, S. and Ali, H. 2014. Seasonal dynamics and land use effect on soil microarthropod communities in midhills of Nepal. Int. J. Agron. Agri. Res., 5(2): 114-123

Benbi, D.K. and Brar, J.S. 2009. Twenty five year record of carbon sequestration and soil properties in intensive agriculture. Agron. Sustainable Development, 29: 257-265.

Cantarello, E., Newtona, A.C., Hill, R.A. 2011. Potential effects of future landuse change on regional carbon stocks in the UK. Environ. Sci. Policy, 14(1): 40 52. doi: 10.1016/j.

Cheng, L., Qi, X., Zhang, X., Li, Q. and Zhang, Y. 2011. Effect of agricultural land use changes on soil nutrients use efficiency in an agricultural area, Beijing, China. Chin. Geogra. Sci., 21(4): 392-402

Feng Xiaoming, Fu Bojie, Yang Xiaojun et al. 2010. Remote sensing of ecosystem services: An opportunity for spatially explicit assessment. Chinese Geographical Sci., 20(6): 522-535. doi: 10.1007/s11769-010-0428-y

Gicheru, P.K. and Kimigo, J. 2012. Impact on soil quality of land use change and continuous cultivation in Sasumua catchment, Kenya. Pedologist, 4: 326331.
Hati, K.M.., Swarup, A., Dwivedi, A., and Misra, A. 2007. Changes in soil physical chemical properties and organic carbon status at the topsoil horizon of a vertisol of central India after 28 years of continuous dropping, fertilization and manuring. Agric. Ecosyst., 119: 127-134

Jackson, M.L. 1973. Soil chemical analysis. Prentice Hall of India Private Limited. New Dehli.

Jing, T., Mingshang, F., Jingheng, G., Petra, M., Xiaolin, L. and Yakov, K. 2012. Effects of land use intensity on dissolved organic carbon properties and microbial structure. European J. Soil Biol., 52: 67-72

Kukal, S.S., Rehanarasool, Benbi, D.K. 2009. Soil organic carbon sequestration in relation to organic and inorganic fertilization in rice-wheat and maizewheat systems. Soil Till. Res., 102: 8792.

Merwin, H.D. and Peech, P.M. 1951. Exchangeability of soil potassium in the sand by nature of complimentary exchangeable cation. Proc. Soil. Sci. Soc. Am., 15: 125-128.

Moges, A., Dagnachew, M. and Fantaw, Y. 2013. Land use effects on soil quality indicators: a case study of Abo-Wonsho southern Ethiopia. Hindawi, 1: 1-9.

Nisar, N. and Lone, F.A. 2013. Effect of land use / land cover change on soils of Kashmir Himalayan catchment. J. Res. Earth and Environ. Sci., 1(1): 13-27

Olsen, S.R., Cole, C.V., Watanabe, F.S. and Dean, L.A. 1954. Estimation of available phosphorus by extraction with sodium bicarbonate, U S Dept. Agric. Citric. 939 p.

Sakin, E. 2012. Organic carbon organic matter and bulk density relationships in arid-semi arid soils in Southeast Anatolia region. Afr. J. Biotechnol., 11: 1373-1377. 
Sigdel, S.R., Pupakheti, D., Baral, U., Tripathea, L., Aryal, R., Dhital, S. and Sharma, P. 2015. Physico-chemical characteristics of soil along attitudinal gradient at southern aspect of Shivapuri Nagarjun national park, central Nepal. Int. Res. J. Earth Sci., 3(2): 1-6

Singh, K., Minhas, R.S., Sharma, I.P. and Razdan, P.N. 1980. Soil survey and land use report of S N Stokes Horticultural complex. Oachghat, Solan. Department of Soil Science and Water Management, H P Krishi Vishva Vidhayalaya, Solan

Sinha, K.S., Mohanty, M., Meena, B.P., Das, H., Chopra, V.K. and Singh, A. 2014.
Soil quality indicators under continuous cropping systems in the arid ecosystem of India. African J. Agri. Res., 9(2): 285-293.

Subbiah, B.W. and Asija, G.L. 1956. A rapid procedure for estimation of available nitrogen in soil. Curr. Sci., 25: 259-260.

Walkley, A.J. and Black, A. 1934. Estimation of soil organic carbon by chromic acid titration method. Soil Sci., 37: 29-38.

Zhang, S., Yang, X., Wiss, M., Grip, H., Lövdahl, L. 2006. Changes in physical properties of a loess soil in china following two long-term fertilization regimes. Geoderma, 136: 579-587.

\section{How to cite this article:}

Ndungu, C.K., S.K. Bhardwaj and Nancy, L. 2017. Impact of Mountain Cropping Systems on Soil Properties, Nutrient Availability and Their Carbon Sequestration Potential in Mid-Hills of Himachal Pradesh. Int.J.Curr.Microbiol.App.Sci. 6(4): 203-211.

doi: https://doi.org/10.20546/ijcmas.2017.604.024 